Extending the teacher educator role: developing tools for working with school mentors

Professional Development in Education

Alaster Scott Douglas

School of Education, University of Roehampton, London, UK

Email: alaster.douglas@ roehampton.ac.uk

Postal Address:

Room E002

Cedar Building

Froebel College

School of Education

University of Roehampton

Roehampton Lane

London SW15 5PJ

UK

ORCID iD: 0000-0003-0972-4315 


\title{
Extending the teacher educator role: developing tools for working with school mentors
}

\begin{abstract}
This article considers the ways a group of university-based teacher educators work with school-based mentors (cooperating teachers). Owing to a number of changes in teacher education policy in England, feelings of marginalisation from the teacher educators are presented before exploring how they undertake their work with school mentors. Using a cultural and historical activity theory lens through which to view interview data, the analysis explores how teacher education activity has changed over the nine years since first interviewing the teacher educators. The findings identify three tools which mediate the work with school mentors. How the teacher educators perceive these tools is analysed in order to compare work intentions driven by the object motive of the teacher education activity with those advocated in the teacher education research literature. Collaborative working practices established by appropriating tools developed from scholarship activity around subject journals, research projects and mentor collectives suggest ways forward for enhancing the teacher educator role. This role is diversifying in teacher education in England with the introduction of new school-based training routes for beginning teachers. Consequently, there is growing need for greater clarity around the work, training and professional development opportunities for teacher educators in England.
\end{abstract}

Keywords: teacher educators, tools, cultural historical activity theory

\section{Introduction}

In a double special issue of this journal in 2010 the focus was on the professional development of teacher educators. What many of the articles highlighted was the challenging aspects of the teacher educator role: the precariousness of the identity switch of the teacher educator when taking on a new academic position after having had a career in school teaching; the lack of induction into the role often best characterised as incidental or occasional learning, and the lack of a clear identity of teacher educators as a professional group (Swennen and Bates 2010). Since this time, developments in teacher education policy 
have meant that for many teacher educators the role has continued to change and arguably has grown more precarious. This has been the case particularly in England where significant structural changes occurring in the process of training new teachers (Marshall 2014) has meant the marginalisation of the traditional 'academic' teacher educator; an educator based in a university working with school partnerships to prepare new teachers (Pereira et al. 2015). University-based teacher education is in competition with new school-based training routes (Department for Education 2011) and there is concern that professional preparation is focusing on practical 'apprenticeship' style approaches rather than inducting beginning teachers into a research informed approach to critical enquiry in the classroom (Author 2015). In other education systems (for example in the USA and in many countries in Europe) the professionalism of teacher educators has also been critically reviewed (Zeichner 2014, Snoek et al. 2011) suggesting that as a professional group the future of teacher educators within Higher Education is under scrutiny, being sidelined and not necessarily secure.

This article considers the findings of a research project which interviewed academic teacher educators and pre-service teachers over a 9 year period. The original research study (a yearlong ethnography based in one secondary school undertaken in 2006) interviewed each university-based teacher educator twice and observed them working with pre-service teachers and mentors in the school setting (Author 2014). The teacher educators were then interviewed for this follow up study in 2015. The initial research explored the experiences of teacher educators when working with school mentors. The current study, through in-depth interviews, explores reflections and responses from the past respondents to developments which have taken place in teacher education over the nine years since the first study. The findings focus on how teacher educators support their role in higher education when many new school-based teacher educators in England are being established in schools (White 2014, O'Dwyer and Atli 2015). The process of increasingly centralised control of initial teacher education in England has only partially been mirrored elsewhere in the UK and Europe. From the 1990s, teacher education policy in England and Wales became more school-focused while many European countries and other nations extended the process of placing teacher education under the auspices of universities.

\section{The challenging and changing nature of the teacher educator role}


Globally, changing educational policy contexts of many governments in relation to teacher education programmes has meant that developing models of teacher education that involve closer links between teachers in schools and teacher educators in universities has become more commonplace (Williams 2014). Reforms to teacher education in the UK over the last 30 years have shifted control and content of pre-service teacher learning from the university to the school classroom (Furlong 2013). In an increasingly school-focused field of teacher education teacher educators need to convince both teachers and pre-service teachers of their credibility in terms of their understanding and expertise in school practice (Griffiths et al. 2010). In England a fragmentation of the school system with the introduction of academy schools may further vary the conditions under which teacher training is undertaken. Academy schools receive their funding direct from central government and not from local councils. They are run by academy trusts which employ the staff. Some academies have sponsors such as businesses, universities, other schools, faith groups or voluntary groups and the sponsors are responsible for improving the performance of their schools (GOV.UK 2016). Such changes in school governance have meant that some schools are no longer required to employ teachers with qualified teacher status (Marshall 2014).

Fragmentation is also seen in the numerous training routes into teaching. There are currently eight routes into teaching, of which six provide $99.9 \%$ of all training places (National Audit Office 2016). These include university-led undergraduate and postgraduate courses, School Direct, School-centred initial teacher training schemes (SCITTs) and Teach First programmes. In England the School Direct programme (Department for Education 2011) introduced in 2012 is the latest step in the gradual shift of teacher education from tertiary providers to schools. School Direct is a scheme set up to give schools control over recruiting and training their own teachers. It promotes more time for novice teachers to learn 'on the job' with schools providing more of the training in-house, buying in other training (from universities or other schools) when needed.

As well as School Direct a number of other alternative training routes are available to preservice teachers in England which may or may not include higher education involvement. School-centred initial teacher training schemes (SCITTs) can operate with schools working with higher education as their accredited provider, or with several schools together without the involvement of a university (TDA 2007). Another employment based route into teaching 
which has minimal university input is the Teach First programme set up in England in 2002 and based on the Teach for America initiative. The programme seeks to attract high qualifying graduates who are placed in secondary schools in challenging circumstances to teach for at least two years (Muijs et al. 2012). Consequently, schools are now getting involved with alternative routes into the profession. Such school-based teacher education work and training activities have led to some schools gaining a 'real enthusiasm on the part of those working in them to engage with Initial Teacher Training' (Mutton and Butcher 2008, p. 56). Perhaps most attractive to schools is the possibility of training teachers 'on the job', as this helps to fill teaching positions and also has the benefit of providing some outside training. The experience of trainees varies depending on the route they follow but all training involves both study of the theory of teaching and practical placements in at least two schools.

In 2011 the government approved its first cohort of teaching schools and established the Teaching Schools Council, a "middle-tier" body set up to co-ordinate teaching schools and their alliances. Teaching schools work with other schools to provide high-quality training and support for school improvement in their local area (GOV.UK, 2016). The development of teaching schools in England with the expectation that they will play a significant role in training teachers further encourages teacher education to primarily take place in the school setting with the partnership of schools and universities changing with regard to their relative input to teacher training. Government papers (for example, Department for Education 2010) indicate that teaching schools will play a fundamental role in developing a self-sustaining system. The role of the university-based teacher educator or teacher educators as a professional group is not referenced in such papers suggesting that the position has little focus in the government's vernacular (White 2014). European policy documents also pay limited attention to the quality of teacher educators although teacher educator professionalism is more strongly focused at the level of some individual Member States. Nevertheless, 'the role of professionals themselves in developing policies to strengthen their professionalism seems very limited' (Snoek et al. 2011, p. 651).

The lack of recognition of the teacher educator role is also mirrored in research on the paucity of induction and training opportunities for new teacher educators (Van Velzen 2010). Researchers have called for more formal preparation for teacher educators that include an understanding of the history of teacher education, current teacher education policy debates, 
the research on the effectiveness of different teacher education programme characteristics, mentoring of teachers, educational theories and the research literature on instructional strategies (Conklin 2015, p. 318). Teacher educators often feel unprepared to assume their role. Research undertaken on 293 teacher educators in the USA found that respondents felt overwhelmed and longed for mentoring and induction support (Goodwin et al. 2014, p. 297). This situation is seen as a consequence of prevailing definitions of teacher education as training; simple work that need not be highly specialised as many perceive themselves as specialist teachers of discipline knowledge. Universities may only hire teacher educators with content specialisation so necessary knowledge is not so much about teacher education pedagogies but about content or discipline knowledge. This contributes to the deprofessionalisation of teacher educating and teacher educators. In the US, there is diminishing political confidence in schools of education as vocal critics question the utility, and even the necessity, of university-based teacher preparation (Goodwin et al. 2014, p. 284).

With differing visions of teacher educators: as a professional teaching force preparing for professional roles and teaching careers or as 'technicians implementing teaching scripts' (Zeichner 2014, p. 552) comes differing views on the identity of the teacher educator. Many teacher educators in the research literature in the UK make the transition from school teaching into academic life (Murray 2008, Maguire 2000, Harrison and McKeon 2008) and struggle to perform traditionally academic roles such as research. Consequently, they often still see themselves as teachers. There are examples in the international research literature of teacher educators who teach in the same institution but differ from one another in their motives, approaches and perceptions of the role and its contribution to how students learn. Perspectives are influenced by personal and institutional variables (Shagrir 2015). Other research refers to the role of the teacher educator as having sub-identities: that of school teacher, teacher in Higher Education, teacher of teachers and researcher (Swennen et al. 2010). Such a role demands the learning of new institutional norms when working with adult learners. This role has been termed 'second order practitioner'; a teacher in higher education rather than a first order practitioner, a school teacher (Murray and Male 2005).

The challenge of the second order practitioner role working with first order practitioners involves managing shifting identities, responding to changing perspectives on teaching and learning and negotiating sometimes finely balanced and difficult relationships. An aspect of 
teacher educator pedagogy that is still relatively unexamined is that of working in schools with mentors (Williams 2014). If the wider context of the learning of teacher educators is not taken into account then workplace learning (at schools and in the university) may lead to reinforcement of conservative perspectives and an uncritical acceptance of taken-for-granted assumptions (i.e. teacher educators may be encouraged to hang on to a school teacher identity rather than an academic one). New teacher educators in higher education may need to be supported to adopt a more critical stance towards their emerging professional identity which may be associated with research activity (Boyd and Harris 2010). Teacher educators are in need of role-models, expert teacher educators who show them what it means to be a good teacher educator (Shagrir 2015, p. 146).

With the new School Direct initiative in England the contribution of university-based teacher educators is diminishing and the role of the School Based Teacher Educator (SBTE) is taking over some of the trainee teacher activity in schools. Being a new role, little research has been undertaken on how this is being enacted in schools. However, there is some unease in the literature regarding the growth of SBTEs in particular with regards to the lack of perceived support and professional learning needs (White et al. 2015). Dutch research (Van Velzen and Volman 2009) shows how SBTEs use Higher Education teacher education tools but rely on their professional knowledge as teachers. This results in pre-service teachers being unable to interpret and elaborate their experience from a theoretical perspective, suggesting that SBTEs need resources, time and training in the new role. The complexity of demands and expectations on SBTEs signal the need for clarity of what it means to be a SBTE (White et al. 2015, p. 5). Suitable opportunities for new SBTEs are needed to integrate them with the wider community of teacher educators for their ongoing professional development. The role of the university-based teacher educator has long been recognised as having potential benefit for offering modelling strategies for school mentors as well as offering written and verbal advice and help by conducting focused observations alongside mentors (Hopper 2001, p. 217). This may encourage mentors to realise the need for some professional detachment in their teacher education work.

The findings of a recent national review on teacher training in England (Department for Education 2015) recommended the development of a set of non-statutory national standards to be developed to help bring greater coherence and consistency to the school-based 
mentoring arrangements for trainee teachers. The Teaching Schools Council was asked to carry out the recommendation and published the 'National Standards for School-Based Initial Teacher Training (ITT) Mentors' in July 2016 (Teaching School Council 2016). Two of the standards explicitly refer to the importance of trainee teachers and mentors engaging with robust research in order to inform their work:

\section{Standard 2 - Teaching:}

The mentor should enable the trainee to access, utilise and interpret robust educational research to inform their teaching ... Standard 4 - Self-development and working in partnership:

The mentor should continue to develop their own mentoring practice and subject and pedagogical expertise by accessing appropriate professional development and engaging with robust research. (Teaching School Council 2016, p.12)

Although the standards for school-based mentors have yet to be implemented, providers of initial teacher training will be expected to adhere to them and plan around them.

\section{The research study}

Eight interviews were semi-structured and qualitative and designed to find out what respondents thought about issues relating to working with mentors in schools and the role of the teacher educator in particular. Definitions of the teacher educator role are growing in diversity and may be broadly seen as anyone who works to support the learning of teachers by taking on mentoring or Continuing Professional Development roles (Murray and Kosnik 2011). However, for this study a distinction is made between those professionals working in teacher education in higher education and those whose work primarily occurs in the school setting. For this paper, the data is taken from the interviews with four university-based teacher educators. Three of these teacher educators had taken part in my 2006 study (Author 2014) and were still in post when interviewing them again in 2015. The other teacher educator had been interviewed by me about his teacher educator role for a previous research project in 2005 when he had worked at the same university as the others but he had not taken part in the 2006 project. Therefore, all respondents were experienced teacher educators and 
they had all been associated with the same university-based teacher education programme for over 10 years.

The Postgraduate Certificate of Education (PGCE) course is a one year university-based programme and remains the most popular entry route to teaching for pre-service teachers in England (Ofsted 2012). Attempts to make teacher education more coherent post 1992 have meant that the broad structure of the PGCE course does share overall characteristics in different education institutions, and can be seen to have distinctive features. Partnership arrangements between schools and universities require some joint responsibility given for planning and managing PGCE courses (including the assessment of pre-service teachers). Legislation stipulates that two thirds of the course takes place in schools and that a minimum of two schools are used (Department for Education 1992). The structure of the school experience requires a specifically designated school-supervising teacher (mentor) who arranges and co-ordinates the placement with the higher education institution. The research university's PGCE was seen as very successful as indicated by numerous reports, including outstanding Office for Standards in Education inspection grades, and positive internal course evaluation outcomes.

Interviews with teacher educators were an effective way of exploring the position taken by them with regards to their experiences as teacher educators over the years since first being interviewed about their work with school mentors. In focusing on understandings rather than checking accuracy of accounts, interviews were also an appropriate way of exploring the conceptual position taken by teacher educators with regard to their work.

The research questions asked:

1. How do you reflect on the changing teacher educator's role in relation to your own experiences in supporting school mentors?

2. In your current experience of working with school mentors, how do you encourage a research-informed approach to critical enquiry?

The data generated examined understandings relating to social, cultural and historical circumstances, and therefore the information was contextually grounded. A semi structured 
and flexible interview strategy was adopted in order to create a guided conversation to elicit rich and detailed information for qualitative analysis. I used a digital recorder, which provided excellent sound quality and enabled me to fully transcribe the interviews. Interviews lasted for approximately 60 minutes. All interviews were conducted in the teacher educators' own offices.

Informed-consent procedures were intended to minimise negative personal and social consequences, and served the purpose of allowing subjects to assess the risks of their participation in the study. A reminder to those involved that everything was on record was evident owing to the conversations being recorded. I was concerned about protecting the identity of respondents. Each was providing information on their understandings, beliefs and attitudes towards their work and aspects of their professional identity. To offer confidentiality was consistent with the aim of empowering respondents in the sense that they retained control over the circumstances under which their personal views entered into the discourse. Anonymity and confidentiality were promised as far as is possible.

\section{The theoretical perspective}

The analysis in the study uses a cultural historical and activity theory (CHAT) lens (Engeström 2008). This focuses attention on working as a social phenomenon, a process that takes place within social systems that have evolved culturally and historically and that offer participants in those systems certain tools with which to work on a shared object. An activity's object is often described as the true motive of an activity (Leont'ev 1981). Understanding how the teacher educators see the object of teacher education is possible by analysing how they work and use tools within the teacher education activity system. Tools are understood as anything that mediates participants' actions upon objects (Russell 2004).

The focus of analysis in Activity Theory first considers the social situation rather than the individual. Considering activity systems (Engeström 1999) instead of individual workplace practices has the advantage of the analysis of work being at the systemic level (exploring how tools are used and objects interpreted and expanded in particular activity systems). Whilst advocating the study of tools as central to how people work, learning in CHAT is considered at the level of the system which includes the rules, community and division of labour inherent 
in the activity. These represent the social/collective elements within an activity system and analysing their interaction is important for appreciating its context and history. The first research question which focuses on the changing teacher educator's role addresses how the respondents view teacher education activity. The data analyses descriptively the concepts that make up the mediational model of activity as described by Engeström (2000, 2001): the rules, community and the division of labour of the teacher education activity system and highlights how these elements are changing. This contextualises the work of the teacher educators and is preparatory for addressing the second research question which explores how their use of tools in teacher education activity is mediating their work with school mentors. The value of these tools and how their appropriation impacts on teacher education activity is explored in the analysis of the second research question.

\section{Findings and discussion}

The first research question asks about the changing teacher educator role as perceived by the teacher educators. Responses from all four teacher educators highlighted a change in teacher education activity specifically in relation to new policy developments in England. Two teacher education developments have had particular impact; the School Direct programme and the school-centred initial teacher training initiative (SCITT). The School Direct programme (McNamara and Murray 2013) has meant that pre-service teachers attending university sessions are now sometimes working alongside pre-service teachers on different routes into teaching. In the research university there was little difference in the student experience for the School Direct students to those students enrolled on the PGCE by the university:

It's pretty much the same set up as they find out pretty swiftly when coming on the course. They are doing exactly the same thing. I think they think they are quite different to start with because they have gone down the School Direct route but they fairly swiftly realise at the end of September they are doing the same thing as the others. They just started in school earlier. (Interview D - 16 July)

Nevertheless, as a consequence of the new School Direct route and the introduction of local SCITTs, some of the teacher educators expressed feelings of vulnerability associated with 
sustaining the university-based teacher education programmes. Pressures have arisen through increasing student numbers with the university supplementing their student cohort with School Direct students.

It makes it all very insecure. Our numbers have gone up because of School Direct and we feel we can't possibly reduce our student allocation as that may get reduced the following year and then we have School Direct on top. So last year it looked like we were going to start with $52 ; 52$ in that room. The previous year we did start with 50 . So we have had more as we have to have our core allocation which we always recruit to. Since I have been here it has gone from about 36 to 46. We now have to bid for next year - a whole new system. We would think about 36 if we could choose. (Interview B 16 July)

Reduced staffing owing to uncertainty over central pre-service teacher allocations has added to the workload: 'losing a third of our full time staff has had the biggest factor recently' (interview B 16 July). And in other areas where subjects are less difficult to recruit to, there is pressure to maintain student numbers by recruiting early before numbers are capped by the government:

I am in a very vulnerable subject in that they wouldn't struggle to recruit teachers even if the only route in was SCITTs because there are so many people that want to be [subject] teachers. It's not the case in shortage subjects and at the moment in shortage subjects university-led partnerships are still recruiting better than alternative options. (Interview C 16 July)

One concern was the effect such recruitment strategies were going to have on the quality of pre-service teachers on courses:

We decided that we would just go for the core numbers for 2016-17. It's going to be a competition basically isn't it, with other higher education providers and then also with the other types of providers. But what will happen is that everybody will try and get their quota by Christmas. You want to get your student teachers in as quickly as possible otherwise you might not fill up the course. That has got 
implications for quality. Not everybody who is the best will apply between October, November and December. Major implications which I don't think they have thought of. (Interview A 16 July)

All teacher educators referred to the concern and frustration of working in constantly shifting teacher education partnerships. The worry is the lack of stability in developing 'a sustained and stable institution that year on year guarantees supply and also excellence. You can't leave it up to the open market' (interview A 16 July).

As mentioned above, the second development which was felt to be out of the control of the teacher educators and the university was the growing number of SCITTs: "whether we will survive the onslaught of the local SCITT I don't know' (interview A 16 July):

The SCITT is the biggest threat here. The SCITT is saying we will do all the training in the school and we will buy you in to do a little bit of doing something else.

And you have declined that?

We have declined the SCITT. To date the local SCITT is only offering subjects which we aren't offering - to date. We shall see in the future what will happen. (Interview A 16 July)

\section{Teacher educator practices}

Feelings of frustration and vulnerability with regard to the impact of alternative routes into teaching were also felt in the daily practices of teacher educators as well as in the macro level policy changes which were impacting on student numbers. The teacher educators expressed feelings about the reduction in their influence on the teacher education process when working with School Direct students and felt their expertise was marginalised by the change in their role:

The mentor had a vision of: you are here to teach and if you can't do it you should get out, rather than you are here to learn to teach. And because we had no influence on who the mentor was, or whether given that that was the mentor there 
should be a placement in that school, we were not able to manage the situation of what happens to the trainee. That then fell to the partnership of schools to manage that. They didn't have the capacity to go and work with the school in the way that we would have sent people in and would have worked with the mentor about their understandings of what the role should be. (Interview C 16 July).

This lack of influence was also apparent in other aspects of the teacher educator's role in relation to the School Direct programme. When sitting on interview panels for prospective pre-service teachers a number of the teacher educators said that they did not agree with the recruitment process:

With School Direct, schools have more involvement in the decision making as to who they are going to have. I have been on a few interviews. Some of the questions and some of the comments in the interviews where the candidates were present were quite scary really; it was usually a senior manager and then the head of department, and what they were expecting and on what basis they were choosing their candidates, it was much more about 'oh she seems like she could fit in, she seems assertive and that is what we need in our classroom'. It put me in an uncomfortable position. (Interview D 16 July)

Similarly, when another teacher educator acted as an examiner on the School Direct programme:

I was questioning why am I here as an external examiner because I don't think anything I say carries any weight here at all? It was clear that my role was really to endorse the judgement of the school. It's not as though the university is in charge but it's usually the collective of mentors with the university that makes decisions. (Interview C 16 July)

The idea of a collective of mentors was felt to be very important by all teacher educators and this is developed further below in the data analysed in relation to the second research question. The importance of a stable community of practice as advocated in the literature was again mentioned in relation to the Teach First 
programme. Although the research university did not work with Teach First, one of the teacher educators had worked on this programme in a previous position at another university and noted the frustrations of working as a teacher educator in that role:

That's what drove me demented about working with Teach First because you have no knowledge of who the mentor will be and there is no mentor community with any stability at all. The pressures in that context to have people who fit into their department that is absolutely what the participant has to do; a second placement is purely an inconvenience. (Interview C 16 July).

Feelings of marginalisation with regards to the university-based teacher educator role have meant that some of the respondents were disillusioned about the changes in teacher education activity:

I haven't even bothered to find out who makes these decisions [how many School Direct students are taken on]. It's not me. That's how I feel at the moment. Nothing I do is decided by me at the moment. Everything has been taken out of my control. If you said, describe how you feel in your professional role at the moment, I would say 'powerless'. And that's at all levels, at my department level and national policy. I have done almost no research this year at all. My research career has gone backwards. (Interview B 16 July)

Another teacher educator suggested that centralised teacher education policies in England appear to illustrate the government's lack of belief in the expertise and professionalism of the teacher educator role:

There isn't enough belief in successive governments that there is a kind of methodology to teacher training or teacher education. It is something people go and look at in schools and they do it and they get a bit of extra input from other sources, and that's it. Therefore, the people who are carrying that out don't need that level of experience, knowledge, skills and understanding. (Interview A 16 July) 
Consequently, recommending that teacher education was only one area of work for academics in higher education was forwarded as a way of protecting job security and developing one's career: 'my advice would be to make sure that it is not the only thing you do. You may find that the programme gets cut and then you haven't got a job' (interview A 16 July).

The rules have changed in teacher education activity which now includes working with different programme providers (for example, school alliances running SCITTs and schools recruiting trainee teachers on the School Direct programme). This has made a difference to working practices as discussed in the examples above and in relation to the working practices with mentors. Schools may work with university-based teacher educators in a managerial role and have considerable say in for example, who is recruited to teacher education programmes and where those pre-service teachers undertake their teaching practices. This has extended the community of participants involved in teacher education activity and has an impact on the division of labour with the development of new roles (SCITT personnel and SBTEs for example).

\section{Teacher educator tools}

The second research question asks about how teacher educators work within the activity of teacher education in order to encourage a research-informed approach to critical enquiry with school mentors. Responses to how work is undertaken with school mentors highlight how tools have been appropriated in order to mediate teacher education work. These tools extend teacher education activity and their appropriation is often valued owing to the changes that have taken place in teacher education as discussed in relation to the first research question. Analysis from the interview data identified three examples of tools being used to strengthen the ways of working with mentors.

\section{The mentor collective}

Believing in the value of collaborative activity and open discussions, the university-based teacher educators identified the mentor community as key to helping develop a researchinformed approach to pre-service teacher education activity: 
It's about the mechanisms of collaboration among mentors and teacher educators and student teachers. There is this tension between knowing what you think is the research evidence and introducing it to the student teachers and mentors and making sure that they take it on board seriously and the idea that they have to gradually become part of that community of practice where they understand the importance of it themselves. (Interview A 16 July)

One teacher educator explained how a new task was introduced for the mentors and pre-service teachers:

We said can we do a school-based task where mentors and student teachers agree to read the same piece of scholarship which might be an article, it might be a chapter; it doesn't have to be a book? All you have to do is read and talk about it together. You might then decide to base some teaching on it or think about what that might mean for the way in which you frame the questions you might ask. We knew we were asking a lot and we collectively discussed this concern with the mentors, and we introduced the task as a result of a mentor meeting. The mentors were generating the suggestions much more formally than we had dared to suggest, so one of the key points of leverage actually is what the other mentors do and suggest. (Interview C 16 July)

Jointly working within a community of practice was felt to be fundamental to the work of teacher educators: 'the fragmentation of individualism is something that has built up over the past 20 years whereby people can't get together and do something' (interview A 16 July).

\section{Scholarship activity}

One teacher educator had taken on an editorial role for a 'Teaching [subject]' journal and was passionate about its importance in inducting practitioners into a community where teachers read scholarship and research and respond to what other teachers are doing and writing: 
It is very definitely a professional journal but is actually determined to bridge the world of academic [subject], [subject] education research and [subject] teaching. So most of its articles are written by teachers, some articles are written by [other professionals in the subject area], some articles are written by researchers and some arise out of different kinds of projects. But we have worked really hard to make it coherent public discourse so it is located in a really rich professional discourse so people cross reference each other's articles and it has built systematically in not any planned way because we always insist that people relate their work to other published work which might be in the journal or elsewhere. So it is not just handy tips of 'this is what I did', it's what's the rationale and how does this relate to what is going on in the professional community? (Interview C 16 July)

This focus on reading and writing and on discussing ideas in relation to teaching and learning was also emphasised in activities connected with the research work the teacher educators had undertaken and were currently pursuing. Again, these conversations were seen as ongoing and directly related to all teacher education activity.

\section{Research}

The three data excerpts below illustrate research activity interacting with teacher education activity:

We do feed it (research) through - we have done a lot of work on [subject] explanations a thing we believe passionately about and that has really fundamentally changed everything we do in our teaching and we actually think all [subject] teachers are good teachers because of that. We have made such a focus on it and we are researching it constantly. (Interview B 16 July)

My research is on the use of tacit knowledge in learning to teach, so what is the place of tacit knowledge for teacher educators and how are student teachers using tacit knowledge? I have been lucky that some of my die hard mentors have been 
very kind and given lots of their time to talk to me about it and have been involved in my research. (Interview D 16 July)

We got together with some local schools and on the basis of research we had done we came up with a series of eight principles. On the basis of those principles, the teachers agreed to produce some videos which were their interpretation of the principles. So it was a way of integrating our work more with that of teachers. We did workshops around the country - seven workshops and hundreds of teachers came to those. (Interview A 16 July)

\section{Working with teacher educator tools}

The process of adopting a tool when working on an object is referred to as 'appropriation' (Leont'ev 1981, Wertsch 1998). This can be seen as a developmental process occurring when using the tool in a social situation. The level at which the tool is appropriated often depends on how closely the subject's values, experiences and goals are aligned with those of more experienced subjects in the environment (Cole 1996). The teacher educators spoke passionately about their collaborative work with mentors and their joint research and scholarship activities. They saw these 'tools' as offering learning opportunities for everyone as they introduced diversity of opinion to the teacher education process and encouraged and guided participants in reflective and ongoing debate. To give an account of culturally mediated thinking it is necessary to specify not only the tools through which behaviour is mediated but also the circumstances in which the thinking occurs (Cole 1996, p. 131). The findings from the first research question help to consider the structures of the social situation in teacher education that afford and constrain the negotiations around the tools' meanings. Feelings of marginalisation on aspects of the teacher educator's role at both a micro and macro level have made the appropriation of these tools especially important for these teacher educators in order to establish 'the stability for investing in a community which is so fundamental to the work' (interview C 16 July).

Working within a community and valuing the co-operative learning of teacher educators and mentors makes it more likely that 'deep reflections and theoretical underpinning can become part and parcel of daily practice' (Boei et al. 2015, p. 16). Researchers considering a 
situation where different work settings interact have referred to this as working within a 'third space'. This term derives from the boundary work of Bhabba (1994) and later of Engeström (2008) where activity systems intersect, as in the overlapping work of teacher educators with pre-service teachers and mentors in higher education and schools. Working in these inbetween spaces puts an emphasis on negotiation, combining ingredients from different contexts to achieve hybrid solutions (Williams 2014). Such work requires 'negotiating a web of relationships' (Martin et al. 2011, p. 305) and is an essential dimension of teacher education, involving the integration of what are often seen as competing discourses in new ways (Zeichner 2010):

The ability to work effectively in this space appears to depend very much on the skills of teacher educators to traverse the sometimes tricky terrain of different professional worlds. Effective communication between teacher educators and mentor teachers is essential if productive learning for all participants in the third space is to occur. (Williams 2014, p. 325)

The tools as described by the teacher educators help them facilitate effective communication about new knowledge and understanding on teaching and learning. The tools also enable them to develop practices that enhance a research-informed approach to teacher education by explicating differences in one another's practices and beliefs and thus learning something new about their own and other's work. Transformation is one of four mechanisms of learning in the third space (Akkerman and Bakker 2011) and may lead to profound changes in practices and potentially the creation of a new in-between practice (which could be initiated from the kind of scholarship and research work as described by the teacher educators). Such collaborative work indicates that all participants in teacher education recognise the shared problem space or object that is being worked on in the activity. An exploratory approach to teacher education acknowledges that work in teacher education may require re-thinking of current practices. This is particularly important for developing transformative work and envisioning new possibilities; breaking away from the given frame of action and taking an initiative to transform it (Engeström et al. 2015).

Resistance in appropriating tools is often evident from fear of additional work and new competence demands (Engeström et al. 2015) and this was experienced on occasions by the 
teacher educators ("the mentor said "I have not got time to do that" interview C 16 July) and yet when work became enriched and meaningful the tools were embraced:

The mentors together were really positive. I did say, are we completely mad to suggest this? The mentors said "this is not mad and it works for us". (Interview C 16 July)

Where mentor learning was seen in similar ways to the learning of teacher educators, as ongoing and specifically in relation to its context then the object of teacher education activity was more clearly identified and its complexity acknowledged. This was reported by the teacher educators when for example the mentor collective developed new tasks with the teacher educator and when developing activities around a subject journal:

There is a real power behind giving beginning teachers articles by practicing teachers, who are clearly reading because they are building on, and challenging and arguing with what other teachers have said. (Interview C 16 July)

This viewpoint is different to one that considers the object of teacher education activity in a less complex way with its principle motive being to develop able practitioners managing classrooms in a manner which 'fits in' with current school practices.

\section{Concluding points}

In several countries the associations of teacher educators have developed standards to support the professional development of teacher educators (USA, Belgium and the Netherlands). Dutch teacher educators can evaluate their performance against the standards in order to register and be certified with VELON (Boei et al. 2015, 2). In the USA the Association of Teacher Educators (2008) has had teacher educator standards in place since 1992. Though informative, like the National Standards for School-Based ITT Mentors (Teaching Schools Council 2016) these standards are voluntary and do not necessarily represent consensus in the field. In a comparison of teacher educator standards from the Netherlands, Australia, Israel, and the United States, Smith (2005) found a great overlap among the main requirements evidencing commonalities across contexts. This could be helpful for defining the teacher 
educator role when there has been a broadening of the possible routes into teaching with consequently the introduction of a number of newly defined teacher educators working in different ways and with different remits than the more traditional 'academic' university-based teacher educator (Pereira et al. 2015). Research suggests that different teacher preparation programmes serve different sectors of the teacher training market. Programmes have different comparative advantages in diverse teacher training settings and therefore policy makers should proceed with caution when trying to identify which programmes are considered the most effective (Lincove et al. 2015).

The Department for Education in England has increased school-led provision in teacher training because it wants schools to have greater autonomy over how they deliver education. The Department aims to encourage school-led routes to expand, by reducing its allocation of places to university-led routes (National Audit Office 2016, p. 15). If 'it is a desire for the work of teachers to be research-informed' (Department for Education 2013) and for Teaching Schools to be engaged in practice-based research (Department for Education 2012) then it is important that teacher educators are engaged in research. It is important for schools and higher education institutions to find ways to work together in partnership to develop 'new forms of affiliation and identity in order to provide opportunities for new teacher educators' (White 2014, p. 447). As alluded to above, adopting a more critical stance may be associated with research activity. There have been calls for supporting the development of the teacher educator role by making research and scholarly activity central to the work of teacher educators, thereby maintaining research-informed teaching in teacher training courses and broadening educational research (Murray 2010). Universities can potentially make important and unique contributions to the education of professional teachers to help them learn how to use research-based teaching: to learn how to learn in and from their practice (Zeichner 2014, p. 561).

Research suggests that teacher learning (for school mentors and SBTEs) should mirror the way university-based teacher educators hope pre-service teacher learning occurs by providing learning opportunities that engage teachers as learners (Conklin 2015, p. 327):

As conceptualisations of the teaching profession become increasingly narrow reflecting a policy environment that favours compliance over creativity, we must 
mobilise frameworks that position pre-service teachers as researchers and problem solvers capable of transforming localised practice through systemic inquiry. (Crawford-Garrett et al. 2015, p. 494)

Considering pre-service teachers undertaking research in teacher education preparation (Author 2014) and the benefits of working within an action research cycle as a core experience for pre-service teachers with collaborative analysis (Conklin 2015) pre-service teachers have found their experience with research transformational. Similarly, the ideal curriculum of professional development for teacher educators honours their autonomy and their ability to reflect on their practices and to integrate these with theoretical frameworks, leading to improved practice and conceptual insights (Ben-Peretz et al. 2010, p. 125). It is also important to note that this process is perceived as occurring in the context of learning communities where school-university collaboration should result in transformative change at the university as well as in schools (Martin et al. 2011, p. 309).

Increased collaboration in the third space provides learning opportunities for both teacher educators and mentors in schools. This has the potential for school teachers to become more involved in the development and delivery of new teacher education activity. The strength of the evidence supporting the interpretation of teacher education activity in this research study is recognised in terms of the limitations of doing a small-scale qualitative interview-only study with teacher educators from one university. The participants are not representative and the data are not viewed as being open to generalisation. However, perspectives within one setting provide rich data that were central to understanding the complexity of teacher education activity and its affordance for providing research-informed learning opportunities.

All interviewees recognised the continuing professional development (CPD) opportunities evident in teacher education activity. Mentor meetings at the university started to have 'a focus on CPD to try and encourage people to come' (interview C 16 July). One of the teacher educators had just taken on a role of co-ordinating broader partnerships with schools embracing CPD and research which had grown out of the teacher education partnerships. SCITTs require school based teacher educators (SBTEs) and one teacher educator commented on how established school-university partnerships have started to impact on new teacher education activity. With the new role of SBTE the university is in a position to attract 
school teachers to train for this role by undertaking study in a number of other courses offered by the university:

The teaching schools alliance is 4 schools; most of the people in the 4 schools have been trained by us in that they have done a PGCE with us and they have done a Masters with us. The Masters becomes a route by which people then move into the SBTE role. As universities find teacher education more and more precarious and they pull out, that becomes the sole point of connection either through the Masters stuff or co-engagement with co-constructed projects. (Interview C 16 July)

Another teacher educator also commented on the Masters courses the research university offers for teachers in order to continue their professional development:

We have also just set up a Masters in Teacher Education which is about if you like, training the trainers for the want of a better word. There are the kinds of things that would come up in a teacher educator development programme. (Interview A 16 July)

These opportunities connected to teacher education activity also impact on it. The new alternative routes into teaching are creating new participants in the teacher education process, increasing the community of practitioners involved and changing the division of labour in the teacher education activity. Tensions experienced in the changing teacher education activity are often around the instability of the system but there are also opportunities for other activities such as CPD to interact with teacher education activity in a positive way:

If it were the case that you could only be a SBTE if you have gone through substantial amounts of training, possibly a Masters or diploma, I think that would be a very good thing. (Interview A 16 July)

The context for teacher education is becoming all the more complex and as it changes, so must the field (Goodwin et al. 2014, p. 299). The speed and complexity of changes in society 
signal the need for teacher educators and teacher education programmes to be more proactive and prominent in their contribution to the change process (Livingston 2016). The role of 'teacher educator' is taken up by different people working in universities, schools and other contexts. Each is likely to have something unique to offer and should be ready to participate in teacher education partnerships and collaborative learning communities. There is also the potential to examine the role others might play in the education of teachers in collaboration with universities such as community-based organisations and educators (Zeichner 2010). This may create more diverse and dynamic third spaces and practices which involve negotiating and renegotiating personal and professional boundaries between different but closely connected sites of professional practice. Boundaries as experiences of learning can be forces for change and development by compelling individuals to reconsider assumptions and look beyond what is already known (Trent 2013). Alongside calls to implement researchinformed teacher preparation must be understandings of how to construct and support rich contexts that serve as transformative settings for teacher learning (Martin et al. 2011, p. 309). Working with teacher educators from a variety of contexts within a stable system in order to facilitate developments of third spaces using the kinds of tools outlined in this study could be a promising start.

\section{References}

Akkerman, S., and Bakker, A., 2011. Boundary crossing and boundary objects. Review of Educational Research. 87 (2), 132-169.

Association of Teacher Educators, 2008. The teacher educator standards. Available at: http://www.ate1.org/pubs/uploads/materialstouse1.pdf (Accessed 7 February 2016)

Ben-Peretz, M., Kleeman, S., Reichenberg, R., and Shimoni, S., 2010. Educators of educators: their goals, perceptions and practices. Professional Development in Education, 36 (1-2), 111-129.

Bhabba, H. K., 1994. The location of culture. New York: Routledge.

Boei, F., Dengerink, J., Geursen, J., Kools, Q., Koster, B., Lunenberg, M., and Willemse, M., 2015. Supporting the professional development of teacher educators in a productive way. Journal of Education for Teaching, DOI: 10.1080/02607476.2015.1080403

Boyd, P. and Harris, K., 2010. Becoming a university lecturer in teacher education: expert school teachers reconstructing their pedagogy and identity. Professional Development in Education, 36 (1-2), 9-24. 
Cole, M., 1996. Cultural psychology: the once and future discipline. Cambridge MA: The Belknap Press of Harvard University.

Conklin, H. G., 2015. Preparing novice teacher educators in the pedagogy of teacher education. Action in Teacher Education, 37 (4), 317-333.

Crawford-Garrett, K., Anderson, S., Grayson, A., and Suter, C., 2015. Transformational practice: critical teacher research in pre-service teacher education. Educational Action Research, 23 (4), 479-496.

Department for Education, 1992. Initial teacher training (secondary phase) (circular 9/92). London: Department for Education.

Department for Education, 2010. The importance of teaching: schools white paper. Available at:

https://www.gov.uk/government/uploads/system/uploads/attachment_data/file/175429/CM7980.pdf [Accessed 7 February 2016]

Department for Education, 2011. Training our next generation of outstanding teachers. Available at:

https://www.gov.uk/government/uploads/system/uploads/attachment_data/file/181154/DFE00083-2011.pdf [Accessed 7 February 2016]

Department for Education, 2012. Teaching schools: a guide for potential applicants. Available at:

https://www.gov.uk/guidance/teaching-schools-a-guide-for-potential-applicants [Accessed 7 February 2016]

Department for Education, 2013. Research priorities and questions: teachers and teaching. Available at:

https://www.gov.uk/government/uploads/system/uploads/attachment_data/file/206722/Resear ch_priorities_and_questions_-_teachers_and_teaching.pdf [Accessed 7 February 2016]

Department for Education, 2015. Carter review of Initial Teacher Training (ITT). London: Department for Education.

Douglas, A.S., 2014. Student Teachers in School Practice: An analysis of learning opportunities. London: Palgrave Macmillan.

Douglas, A. S., 2015. A new research agenda for teacher education: the value of a partnership approach to classroom-based research. TEAN Journal, 7(1), 3-13.

Engeström, Y., 1999. Activity theory and individual and social transformation. In: Y. Engeström, R. Miettinen and R. L. Punamaki, eds. Perspectives on activity theory. Cambridge: Cambridge University Press, 19-38.

Engeström, Y., 2000. Activity theory as a framework for analysing and redesigning work. Ergonomics, 43 (7), 960-974. 
Engeström, Y., 2001. Expansive learning at work: toward an activity theoretical reconceptualization. Journal of Education and Work, 14 (1), 133-156.

Engeström, Y., 2008. From teams to knots: activity-theoretical studies of collaboration and learning at work. Cambridge: Cambridge University Press.

Engeström, Y., Kajamaa, A., and Nummijoki, J., 2015. Double stimulation in everyday work: critical encounters between home care workers and their elderly clients. Learning, Culture and Social Interaction, 4, 48-61.

Furlong, J., 2013. Education - an anatomy of the discipline: rescuing the university project? Abingdon: Routledge.

Goodwin, A. L., Smith, L., Souto-Manning, M., Cheruvu, R., Tan, M., Reed, R., and Taveras, L., 2014. What should teacher educators know and be able to do? Perspectives from practicing teacher educators. Journal of Teacher Education, 65 (4), 284-302.

GOV.UK, 2016. Types of schools. Available at: https://www.gov.uk/types-ofschool/academies (Accessed 3 August 2016)

Griffiths, V., Thompson, S., and Hryniewicz, L., 2010. Developing a research profile: mentoring and support for teacher educators. Professional Development in Education, 36 (12), 245-262.

Harrison, J., and McKeon, F., 2008. The formal and situated learning of beginning teacher educators in England: identifying characteristics for successful induction in the transition from workplace in schools to workplace in higher education. European Journal of Teacher Education, 31 (2), 151-168.

Hopper, B., 2001. The Role of the HEI tutor in initial teacher education school-based placements. Mentoring and Tutoring: Partnership in Learning, 9 (3), 211-222.

Leont'ev, A.N., 1981. The problem of activity in psychology. In: J.V. Wertsch, ed. The concept of activity in soviet psychology. New York: Armonk NY 37-71.

Lincove, J.A., Osborne, C., Mills, N., and Bellows, L., 2015. Teacher preparation for profit or prestige: analysis of a diverse market for teacher preparation. Journal of Teacher Education, $66(5), 415-424$.

Livingston, K., 2016. Teacher education's role in educational change. European Journal of Teacher Education, 39 (1), 1-4 http://dx.doi.org/10.1080/02619768.2016.1135531

Maguire, M., 2000. Inside / outside the ivory tower: teacher education in the academy. Teaching in Higher Education, 5 (2), 149-165.

Martin, S. D., Snow, J. L., and Franklin Torrez, C. A., 2011. Navigating the terrain of third space: tensions with/in relationships in school-university partnerships. Journal of Teacher Education, 62 (3), 299-311. 
Marshall, T., 2014. New teachers need access to powerful educational knowledge. British Journal of Educational Studies, 62 (3), 265-279.

McNamara, O., and Murray, J., 2013. The school direct programme and its implications for research-informed teacher education. In: Learning to Teach Part 1. Available at:

https://www.heacademy.ac.uk/sites/default/files/resources/learningtoteach_part1_final.pdf (Accessed 7 February 2016)

Menter, I., Hulme, M., and Murray, J. 2010. Teacher education research in the UK: the state of the art. Swiss Revue of Education, 1, 34-48.

Muijs, D., Chapman, C., and Armstrong, P., 2012. Teach first: pedagogy and outcomes: the impact of an alternative certification programme. Journal for Educational Change, 4 (2), 2964.

Murray, J., 2008. Teacher educators' induction into higher education: work-based learning in the micro-communities of teacher education. European Journal of Teacher Education, 31 (2), 117-133.

Murray, J., 2010. Towards a new language of scholarship in teacher educators' professional learning? Professional Development in Education, 36 (1-2), 197-209.

Murray, J., and Male, T., 2005. Becoming a teacher educator: evidence from the field. Teaching and Teacher Education, 21, 125-142.

Murray, J., and Kosnik, C., 2011. Introduction: academic work and identities in teacher education. Journal of Education for Teaching, 37 (3), 243-246.

Mutton, T., and Butcher, J., 2008. We will take them from anywhere: schools working within multiple initial teacher training partnerships. Journal of Education for Teaching, 34 (1), 45 62.

National Audit Office, 2016. Training new teachers: Report by the Controller and Auditor General. Available at: https://www.nao.org.uk/wp-content/uploads/2016/02/Training-newteachers.pdf (Accessed 3 August 2016)

O’Dwyer, J., and Atli, H., 2015. A study of in-service teacher educator roles, with implications for a curriculum for their professional development. European Journal of Teacher Education, 38 (1), 4-20.

Ofsted, 2012. Annual Report 2010/11: Initial Teacher Education. London: Office for Standards in Education.

Pereira, A., Lopes, A., and Marta, M., 2015. Being a teacher educator: professional identities and conceptions of professional education. Educational Research, 57 (4), 451-469. 
Russell, D. R., 2004. Looking beyond the interface, activity theory and distributed learning. In: H. Daniels and A. Edwards, eds. The Routledge Falmer Reader in Psychology of Education. London: Routledge Falmer, 307-326.

Shagrir, L., 2015. Working with students in higher education: professional conceptions of teacher educators. Teaching in Higher Education, DOI: 10.1080/13562517.2015.1085854

Smith, K., 2005. Teacher educators' expertise: what do novice teachers and teacher educators say? Teaching and Teacher Education, 21, 177-192.

Snoek, M., Swennen, A., and Van der Klink, M., 2011. The quality of teacher educators in the european policy debate: actions and measures to improve the professionalism of teacher educators. Professional Development in Education, 37 (5), 651-664.

Swennen, A., and Bates, T., 2010. The professional development of teacher educators. Professional Development in Education, 36 (1-2), 1-7.

Swennen, A., Jones, K., and Volman, M., 2010. Teacher educators: their identities, subidentities and implications for professional development. Professional Development in Education, 36 (1-2), 131-148.

TDA, 2007. Guidance to accompany the requirements for initial teacher training. London: TDA.

Teaching Schools Council, 2016. National standards for school-based initial teacher training (ITT) mentors. Available at:

https://www.gov.uk/government/uploads/system/uploads/attachment_data/file/536891/Mento r_standards_report_Final.pdf (Accessed 3 August 2016)

Trent, J., 2013. Becoming a teacher educator: the multiple boundary-crossing experiences of beginning teacher educators. Journal of Teacher Education, 64 (3), 262-275.

Van Velzen, C., Van der Klink, M., Swennen, A., and Yaffe, E., 2010. The induction and needs of beginning teacher educators. Professional Development in Education, 36 (1-2), 6175.

Van Velzen, C., and Volman, M., 2009. The activities of a school-based teacher educator: a theoretical and empirical exploration. European Journal of Teacher Education, 32 (4), 345367.

Wertsch, J., 1998. Mind as Action. Oxford: Oxford University Press.

White, E., 2014. Being a teacher and a teacher educator: developing a new identity? Professional Development in Education, 40 (3), 436-449.

White, E., Dickerson, C., and Weston, K., 2015. Developing an appreciation of what it means to be a school-based teacher educator. European Journal of Teacher Education, DOI: 10.1080/02619768.2015.1077514 
Williams, J., 2014. Teacher educator professional learning in the third space: implications for identity and practice. Journal of Teacher Education, 65 (4), 313-326.

Zeichner, K., 2010. Rethinking the connections between campus courses and field experiences in college- and university-based teacher education. Journal of Teacher Education, 61 (1-2), 89-99.

Zeichner, K., 2014. The struggle for the soul of teaching and teacher education in the USA. Journal of Education for Teaching: International research and pedagogy, 40 (5), 551-568. 